\title{
Solar Photovoltaic and Thermal Energy Systems: Current Technology and Future Trends
}

\author{
Mariusz Malinowski, Fellow Member, IEEE, Jose I. Leon, Fellow Member, IEEE, \\ and Haitham Abu-Rub, Senior Member, IEEE
}

\begin{abstract}
Solar systems have become very competitive solutions for residential, commercial and industrial applications for both stand-alone and grid connected operations. This paper presents an overview of the current status and future perspectives of solar energy (mainly photovoltaic) technology and the required conversion systems. The focus in the paper is put on the current technology, installations challenges, and future expectations. Various aspects related to the global solar market, the PV modules cost and technology, and the power electronics converter systems are addressed. Research trends and recommendations for each of the PV system sectors are also discussed.
\end{abstract}

Index Terms-Photovoltaic systems, Renewable energy sources, Solar power generation.

\section{INTRODUCTION}

C URRENTLY, the reliable and resilient energy systems are based on fossil fuels burning which are still dominating worldwide. However, fossil fuels are non-renewable and directly emit greenhouse gases to the environment. This has been leading to serious environmental and health impacts. Furthermore, the fluctuating price of the fossil fuels has serious impact on the energy security.

There are several alternative resources that can provide clean, continuous, and renewable energies such as hydropower, solar, wind, biomass, and geothermal. Nuclear energy is potential, however its use brings huge safety risks, therefore as this, it can not be deemed as clean or safe source.

Renewable energy sources (RES) are receiving significant attention worldwide as a sustainable alternative type of energy supply being an important sector of the global energy generation [1]. Renewable energies are expected to overtake coal around 2030 to become the largest power source and achieving 34\% of total energy generation on 2040 as shown in Fig. 1 [2]. The renewable energy growth rate in different

Manuscript received January 30th, 2017; revised March 26th, 2017; accepted March 27th, 2017. This paper was made possible by the NPRP-EP grant \#[X-033-2-007] from the Qatar National Research Fund (a member of Qatar Foundation), the TEAM-TECH/2016-1/5 project carried out within the TEAM-TECH programme of the Foundation for Polish Science cofinanced by the European Union under the European Regional Development Fund, the Andalusian Science and Innovation project P11-TIC-7070, and the Spanish Science and Innovation Ministry under project TEC2016-78430-R. The statements made herein are solely the responsibility of the authors.

Mariusz Malinowski is with the Institute of Control and Industrial Electronics, Warsaw University of Technology, Poland (e-mail: malin@ee.pw.edu.pl).

Jose I. Leon is with the Electronic Engineering Department, Universidad de Sevilla, Spain (e-mail: jileon@us.es).

Haitham Abu-Rub is with the Electrical \& Computer Engineering Program, Texas A\&M University at Qatar, Qatar (e-mail: haitham.aburub@qatar.tamu.edu).
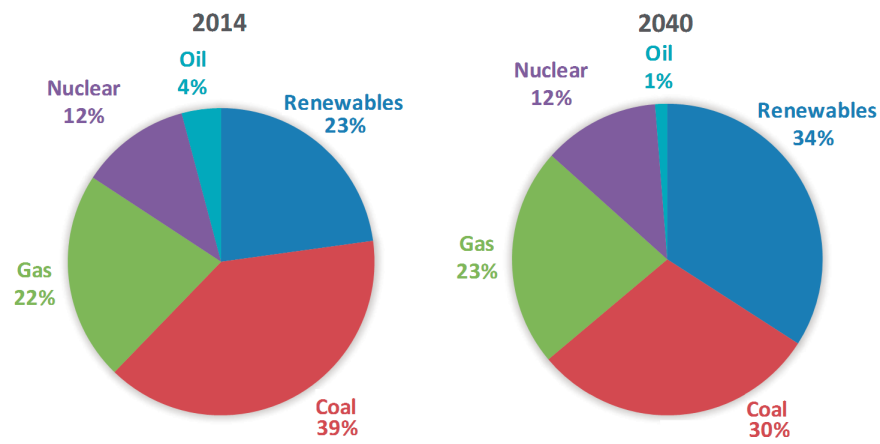

Fig. 1: Global electricity generation

areas is increasing sharply with promising target as shown in Fig. 2.

RES are clean and environmental friendly resources, hence play an important role in reducing greenhouse gas emissions. Investing in RES would help in reaching little to no global warming effects and gas emissions, which helps in improving public health and in protecting our environment [3]. This improves human life quality by providing enormous and inexhaustible energy supply, with more jobs, and other economic benefits such as stable energy prices. Wide spread of RES has more benefits than aforementioned economic, health and environmental aspects [4]. There are many political, social and technical advantages of adopting renewable energies. Among those are: energy security and self-sufficiency, industry development, local ownership and public decision making, community building and empowerment. Energy security is priceless; it justifies all efforts and expenditures being put for adopting the renewables and in particular the distributed form of them [5].

RES have gone a rapid growth in the last ten years and are forecasted to lead world power market growth to 2020 [4]. Solar energy has gained the highest attention (highest growth rate) worldwide in the last years. This is because of potential availability, good visibility, and safe use for small and large scales by residential, commercial, and utility-scale users. From 2009 to 2015, the solar power capacity has been multiplied by a factor around 100 [6].

The highest addition rate among the renewables is the solar PV as seen from Fig. 2 [7]. PV power installations and the related research are increasing rapidly. Some market analysts expect the PV installation could reach $25 \%$ of generated energy by 2050 [8]. The price of PV systems has decreased above $50 \%$ in five years [9]. Figure 3 shows trends of installation 


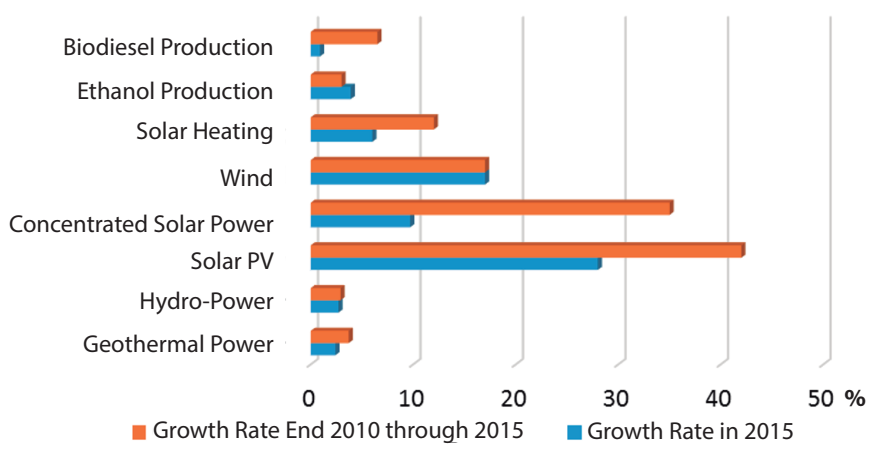

Fig. 2: Average annual growth rates of solar energy production - 2010 to 2015

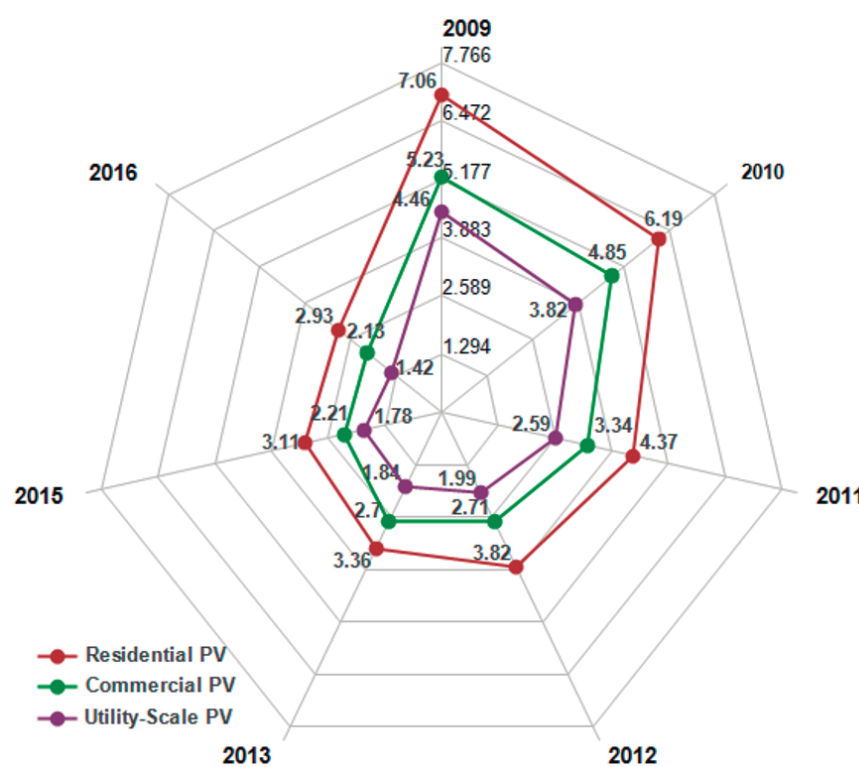

Fig. 3: Installation prices of residential, commercial and utility scale PV systems

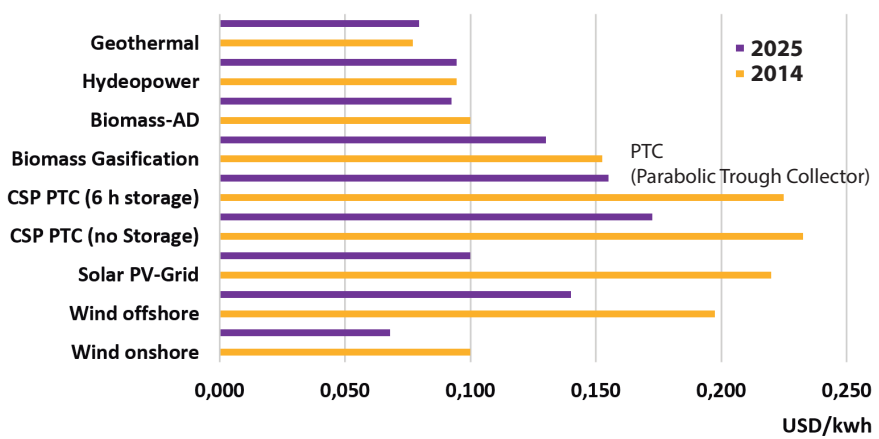

Fig. 4: Worldwide capital costs expectations of various energy resources in 2025 compared to 2014

prices of residential and commercial PV systems [10]. For the installation of large-scale PV power systems, prices are commonly below $1.79 \mathrm{USD} / W$ now. In particular places and times, the cost of PV power may be competitive with the generated from coal or gas. For instance, the capital costs per watt of building various power plants is shown in Table I for
TABLE I: US Capital Costs of Different Energy Resources in 2016

\begin{tabular}{|c|c|c|}
\hline Energy Sources & $\begin{array}{l}\text { Capacity } \\
\text { (MW) }\end{array}$ & $\begin{array}{l}\text { Capital cost } \\
\text { (USD/kW) }\end{array}$ \\
\hline \multicolumn{3}{|l|}{ COAL } \\
\hline Ultra Supercritical Coal (USC) & 650 & 3636 \\
\hline USC with CCS (USC/CCS) & 650 & 5084 \\
\hline $\begin{array}{l}\text { Pulverized Coal (PC) Conversion to Natural } \\
\text { Gas }\end{array}$ & 300 & 226 \\
\hline $\begin{array}{l}\text { PC Greenfield with } 10-15 \% \text { biomass } \\
\text { (GCBC) }\end{array}$ & 300 & 4620 \\
\hline $\begin{array}{l}\text { PC Conversion to } 10 \% \text { biomass - } 30 \mathrm{MW} \\
\text { (CTCB) }\end{array}$ & 300 & 537 \\
\hline \multicolumn{3}{|l|}{$\begin{array}{ll}\text { NATURAL GAS (NG) } \\
\end{array}$} \\
\hline NG Combined Cycle (NGCC) & 702 & 978 \\
\hline Advanced NG Combined Cycle (ANGCC) & 429 & 1104 \\
\hline Combustion Turbine (CT) & 100 & 1101 \\
\hline Advanced Combustion Turbine (ACT) & 237 & 678 \\
\hline $\begin{array}{l}\text { Reciprocating Internal Combustion Engine } \\
\text { (RICE) }\end{array}$ & 85 & 1342 \\
\hline \multicolumn{3}{|l|}{\begin{tabular}{|l} 
URANIUM \\
\end{tabular}} \\
\hline Advanced Nuclear (AN) & 2234 & 5945 \\
\hline \multicolumn{3}{|l|}{ BIOMASS } \\
\hline Biomass (BBFB) & 50 & 4985 \\
\hline \multicolumn{3}{|l|}{ WIND ENERGY } \\
\hline Onshore Wind & 100 & 1877 \\
\hline \multicolumn{3}{|l|}{ SOLAR ENERGY } \\
\hline Photovoltaic - Fixed & 20 & 2671 \\
\hline Photovoltaic - Tracking & 20 & 2644 \\
\hline Photovoltaic - Tracking & 150 & 2534 \\
\hline
\end{tabular}

data from 2016 based on the US market [11]. The worldwide cost reduction of PV systems since that made the PV system an economically competitive investment for longer run. Figure 4 shows the worldwide capital costs expectations of various energy resources in 2025 compared to those in 2014 [12]. The grid-connected solar PV system has promising reduction to be competitive with most of energy sources.

The main application of solar energy systems is to act as clean power source connected to the electrical grid [13]. However, there are many additional applications of solar energy such as, solar water pumps in stand-alone and grid interfaced systems [14], solar feeding of the telecommunication base towers which is cost effective particularly for remote areas [15], [16], solar energy in building managements systems [17]-[19], solar energy in micro-grids, smart grid and distributed generation [20], [21], charging infrastructures of electric vehicles [22], solar energy for marine, satellite, and many other applications.

\section{TyPES OF SOLAR ENERGy SyStems}

Today's market of the solar power systems can be categorized into two types: the thermal and PV solar power. Direct use of thermal energy for water heating is very mature and relatively old technology with global capacity over 400 GW-thermal. For electricity generation, the concentrated solar power (CSP) is a promising technology indirectly generating 


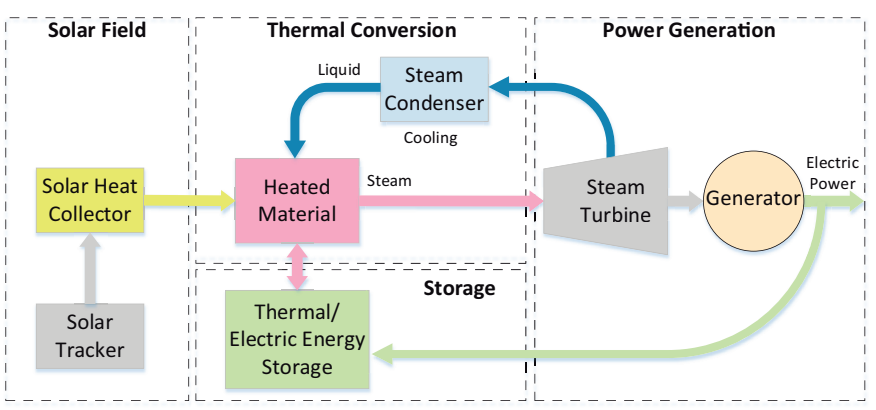

Fig. 5: Block diagram of a concentrated solar power system

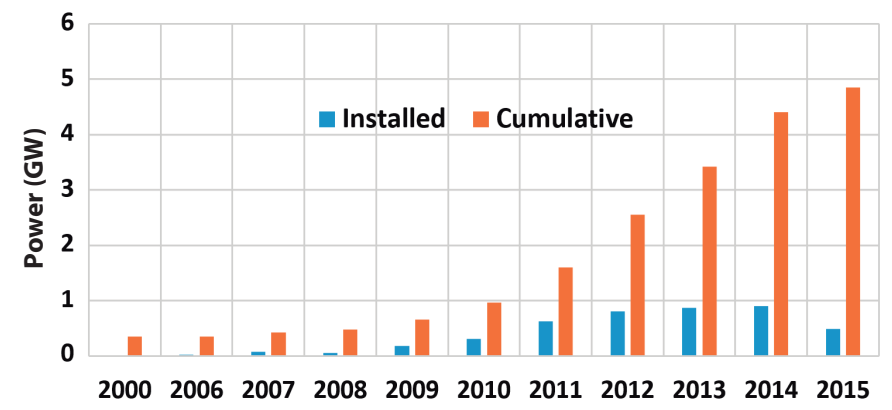

Fig. 6: Evolution of worldwide CSP electrical generated energy

electricity, which is adopted particularly in high power generation plants.

\section{A. Concentrated Solar Power}

Concentrated solar power (CSP) could be categorized as indirect. The first type of CSP converts the solar energy first to heat and then to electricity, which is the thermal CSP. This technology uses lenses or mirrors and tracking systems to concentrate solar irradiance to heat a solid, liquid, or gas. It directs the large area of sunlight into a small area (focal point) to produce heat and/or electricity. The block diagram of a CSP system is presented in Fig. 5. Examples of concentrating technologies include parabolic trough and power tower, dish stirling, concentrating linear fresnel reflector, and solar chimney [23]. Over $60 \%$ of the applications use long parabolic trough systems. Such plants may achieve at least $25 \%$ efficiency. Power Tower based plants may have a capacity factor around 40\% [24].

The second type of CSP systems is the photovoltaic. Concentrating photovoltaic (CPV) systems concentrate the sunlight into PV surfaces for producing electricity. It is categorized as indirect method because the sunlight is first concentrated, then converted into electricity.

A hybrid method is a combination (photovoltaics and thermal) that is used to produce electricity in addition to thermal heat.

Thermal heat can be used for water heating, solar cooling (heat-powered air conditioning), and water desalination. Solar thermal processes have various temperature and pressure requirements with different heat conducting and storing materials, such as steam, hot water, and thermal oil. CSP technology is now acquiring an increasing interest, especially if built with thermal energy storage. Thermal systems allow storing energy for several hours longer than other technologies.

Figure 6 shows the worldwide CSP electrical generated energy [7], [25]. It can be observed that the global generated capacity is relatively low. Regardless the relatively higher efficiency of the CSP systems, they have been and being deemphasized by the PV systems for many reasons, such as significantly higher installation and running costs, continuous decrease of the PV panels cost, and higher sensitivity of CSP system than of the PV to the environmental conditions such as dust and humidity. Some particles of the dust may affect not only the efficiency but also directions of solar beams to the focal point of the plant. Furthermore, the CSP systems are mainly applicable for higher power generation which requires special attention, location, cleaning, and investment [26].

\section{B. Solar PV Technology}

The direct solar power or solar PV power refers to a system that converts solar radiation directly to electrical form of energy using PV cells [27]-[29]. This type of renewables presents the highest global attention because of its numerous advantages. The advantages of this technology are: quiet energy conversion, easy design and installation, nice architectural visibility, long lifetime with less maintenance requirement, easy transportation and light weight, and acceptable price with significant dropping rate.

The cost of the PV systems has dropped dramatically in the last years and expected to continue dropping (see Fig. 7) [30]. From 2009 to 2015, there was 56\% reduction in the total cost, $77 \%$ in the PV modules, $45 \%$ in inverter cost, and $44 \%$ in installation-related costs. All this helped in promoting this technology worldwide as a possible alternative to all other energy sources, renewables and traditional. Figure 8 and Fig. 9 show the world trend in adopting this area of clean and renewable energy [6], [31], [32].

The globally installed PV power capacity has had a remarkable increase since 2009. The PV penetration of total electricity generating capacity is gradually rising in several countries with expectations through 2018, except a sharp increase in Japan since 2012, as shown in Fig. 9 [32].

The grid-connected solar PV is the most promising technology for solving future energy demands. The research related to $\mathrm{PV}$ is currently concentrated on the improvement and solutions for higher efficiency and lower price of the PV panels and systems, capturing the maximum possible amount of energy from the PV panels using efficient maximum power point tracking (MPPT) methods [33], power electronics converters for stand-alone and grid connections, developing efficient PV power converter topologies, solving the power quality challenges with grid-tie systems, reliable and cost effective storage, and integrating with smart grid systems [34]-[36].

\section{The Solar Cell}

The solar cell is made from solid state material that converts the energy of light (photons) into electric form using the photovoltaic effect. Solar cells are also called PV cells and 
TABLE II: Top Ten Largest Solar PV Plants in the World [37]

\begin{tabular}{ccllc}
\hline \hline Ranking & Power (MW) & Project & Location & On Grid \\
\hline 1 & 579 & Solar Star Projects & Rosamond, California, USA & 2015 \\
2 & 550 & Desert Sunlight Solar Farm & Riverside County, California, USA & 2015 \\
3 & 550 & Topaz Solar Farm & San Luis Obispo County, California, USA & 2015 \\
4 & 530 & Longyangxia Dam Solar Park facility & Qinghai, China & 2013 \\
5 & 500 & Golmud Solar park & Qinghai, China & 2011 \\
6 & 458 & Copper Mountain Solar Facility & Boulder City, Nevada, USA & 2015 \\
7 & 345 & Charanka Solar Park & Gujurat, India & 2012 \\
8 & 300 & Cestas Solar Farm & Bordeaux, France & 2015 \\
9 & 290 & Agua Caliente Solar & Yuma County, Arizona, USA & 2014 \\
10 & 250 & California Valley Solar Ranch & San Luis Obispo, California, USA & 2013 \\
\hline \hline
\end{tabular}

photoelectric cells. As an example, the characteristic curves of a commercial PV module is represented in Fig. 10 where the behavior with the solar irradiance of one PV module is highlighted. The short-circuit current $\left(I_{s c}\right)$ and the open-circuit voltage $\left(V_{o c}\right)$ are the main basic parameters of the PV module. In any case, taking into account the actual solar irradiation $\left(\mathrm{W} / \mathrm{m}^{2}\right)$ and the temperature, the optimum operation point of the PV module is the point with maximum extracted power $\left(P_{m p}\right)$. Capturing the maximum power in any condition (temperature and irradiation) is essential and is achieved by efficient maximum power point tracking (MPPT) algorithms.

There are different types of materials used for the design of PV cells. The crystalline materials used for cells design are single crystalline (sc-Si) with a Czochralski (CZ) float zone (FZ) technology, multicrystalline (mc-Si) with a cast, sheet, ribbon growth technology, polycrystalline (pc-Si) with a chemical-vapour deposition technology, and microcrystalline (mc-Si) with a plasma deposition. One main difference between those materials is the regularity level and structure, which affects the size of the crystals making such material.

There are other types of solar cells such as thin film, including amorphous silicon (a-Si), cadmium telluride $(\mathrm{CdTe})$, and copper indium gallium selenide $(\mathrm{CI}(\mathrm{G}) \mathrm{S})$ [38]. Additional types may be also found such as desensitized solar cell (DSSC), gallium arsenide germanium solar cell (GaAs), luminescent solar concentrator cell (LSC), multi-junction solar cell (MJ), organic solar cell (OPV), perovskite solar cells, photoelectron chemical cells (PEC), plasmonic solar cells, plastic solar cells, polymer solar cells, quantum dot solar cells, etc.

Efficiencies of solar PV cells converting the energy of light's photons to electric energy are different [24]. However, the output power of PV panels is sensitive to the environmental conditions such as solar irradiation intensity, ambient temperature, and dust. The efficiency of commercial PV panels is still relatively low but in the last decade the efficiency of average commercial wafer-based silicon modules have increased for about $5 \%$ (from about $12 \%$ to $17 \%$ ) [39]. Commercial thin film solar cells have increased significantly. As an example, CdTe modules efficiency have raised from $9 \%$ to $18.6 \%$ (commercialized by First Solar in 2015).

Nevertheless, there are promising data on the available and foreseen technologies. Figure 11 shows the progress in PV cells efficiency development using laboratory solar cells as example [24]. In the laboratory, the best performing monocrystalline silicon models are with about $25.6 \%$ efficiency. Also in the laboratory, the high concentration multi-junction solar cells achieved up to $46.0 \%$ efficiency. Figure 11 indicated some improvement trend but this is not enough. There is still much research and development needed in this direction. Recorded efficiencies demonstrate the need for further efficiency improvement at the production level. This is a major

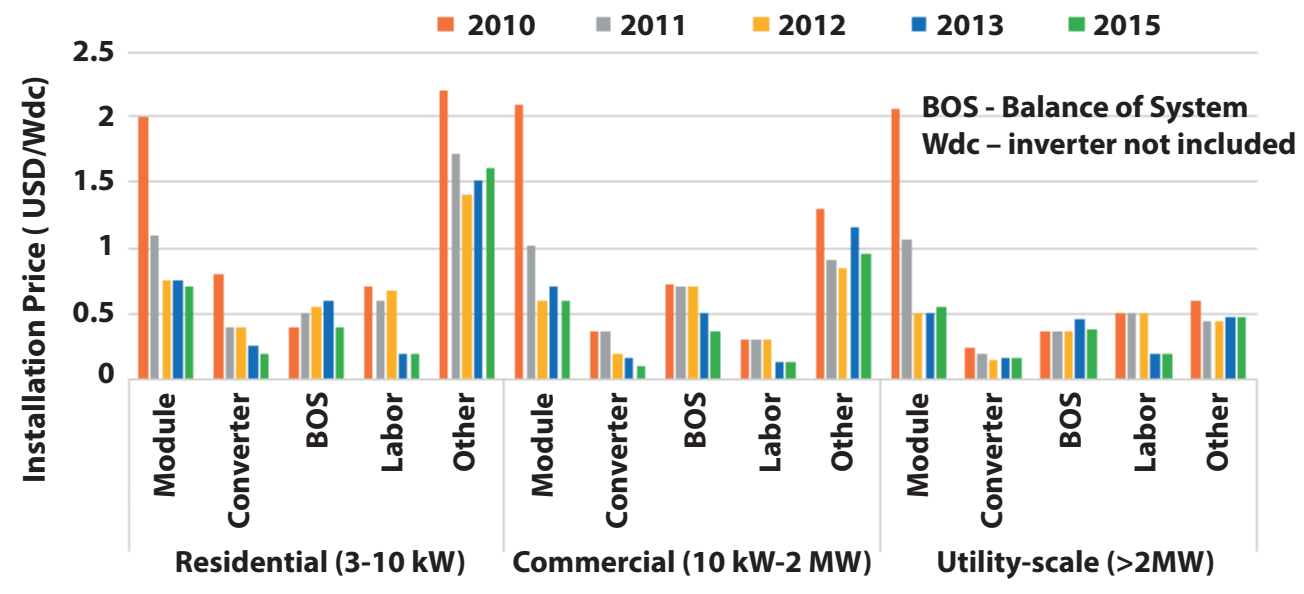

Fig. 7: The evolution of the cost distribution of residential, commercial and utility-scale PV systems 


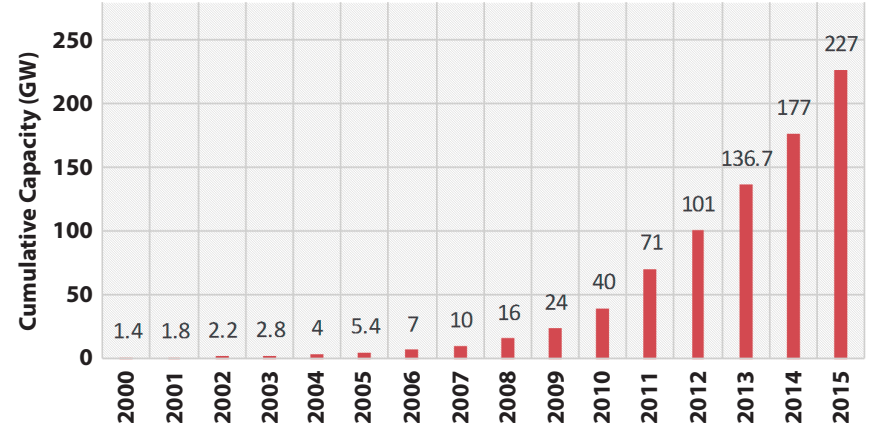

Fig. 8: Globally installed PV power capacity (until 2015)

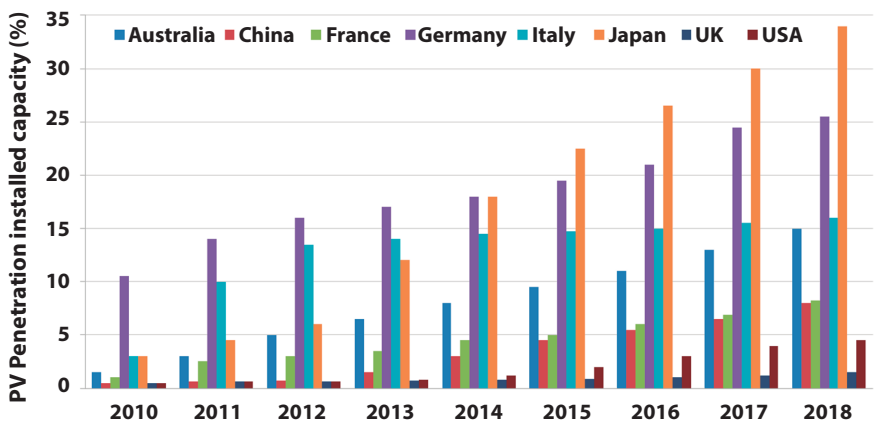

Fig. 9: PV penetration of total electricity generating capacity (expected since 2015)

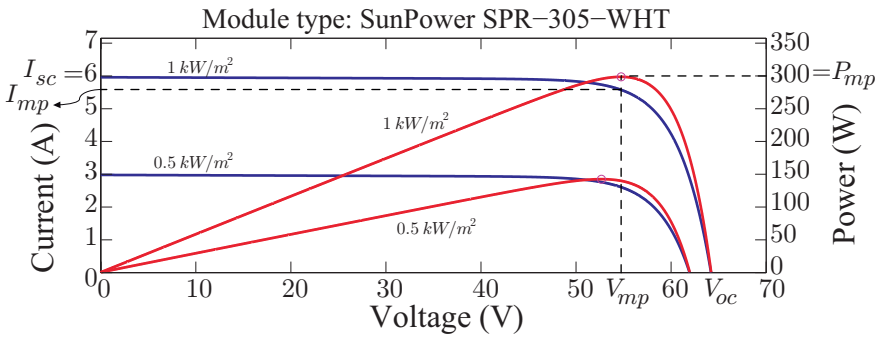

Fig. 10: Characteristic curves of a commercial PV panel including the solar irradiance variation

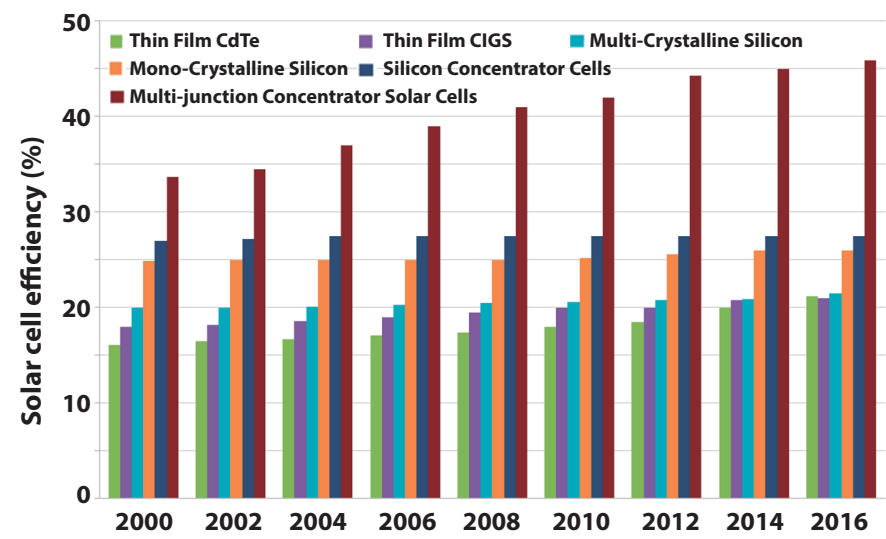

Fig. 11: Development of laboratory solar cell efficiencies

challenge for future research that to potentially increase the efficiency of PV panels at production scale with a reasonable price.

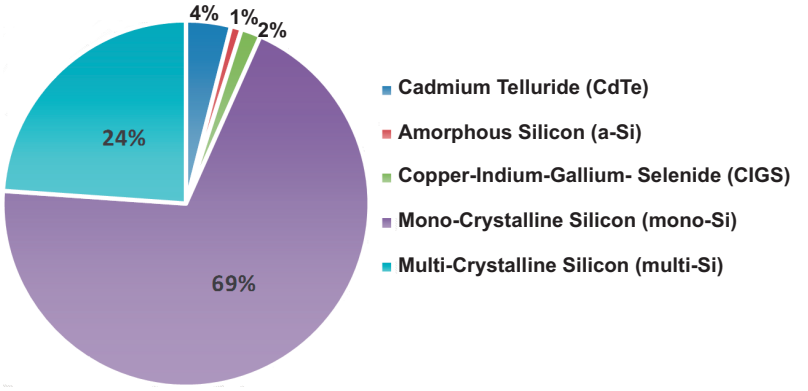

Fig. 12: Global PV market by technology in 2015

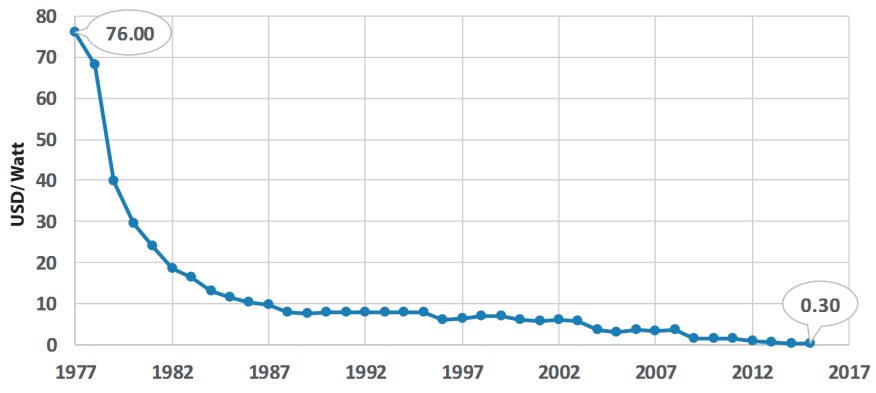

Fig. 13: Price history of silicon solar cells

For the global PV market, thin-film technologies took up around $7 \%$ of worldwide disposition, including $4 \%$ in CdTe and $2 \%$ in CIGS and $1 \%$ in a-Si; while $93 \%$ was held by crystalline silicon (mono-Si and multi-Si) in 2015, as shown in Fig. 12 [39]. In addition, mono-Si is still dominant in $69 \%$.

With the improving technology in semiconductors, there has been a significant drop for the price per watt of solar cells over the last two decades. Figure 13 shows the price history of silicon solar cells. The price for crystalline silicon cells was about 76 USD/ $W$ in 1977 prices, while average prices in 2015 was as low as $0.30 \mathrm{USD} / W$, which is 200 times less than forty years ago. Prices for thin-film solar cells were around 0.55 $\mathrm{USD} / W$ in 2016 [40].

\section{General Scheme of a Solar PV System}

The PV cells arranged into panels could be used in largescale PV projects. A rooftop PV system may be comprised of tens or hundreds of panels, while a large-scale project may consist of thousands or even millions of panels.

Utility-scale PV plants are commonly installed in remote areas, as Table II lists for the top ten large-scale PV farms [37]. Large-scale PV systems have been a major part of PV's growth in recent years. They contributed above $50 \%$ of all solar capacity assembled from 2010 to 2014, with overall capacity quadrupling from 2012 to 2014 [41].

Rooftop systems as distributed generation sources are excellent tools for creating future smart grid systems. Such kind of systems have the chance to grow most over the world at residential and commercial scales.

The typical power configuration of a PV system (for stand-alone or grid-connected applications) is represented in Fig. 14 [42]. The solar photovoltaic cells, arranged forming 


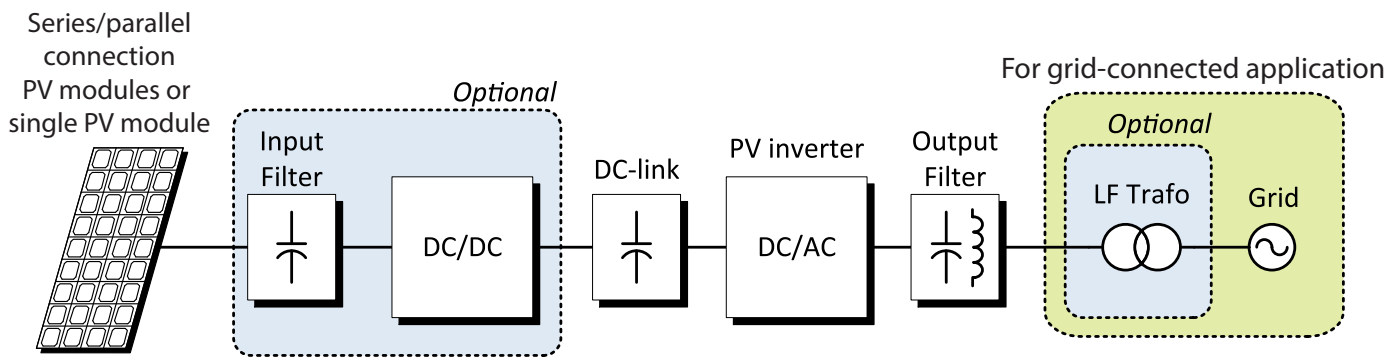

Fig. 14: General scheme of a PV system for grid-connected or stand-alone applications

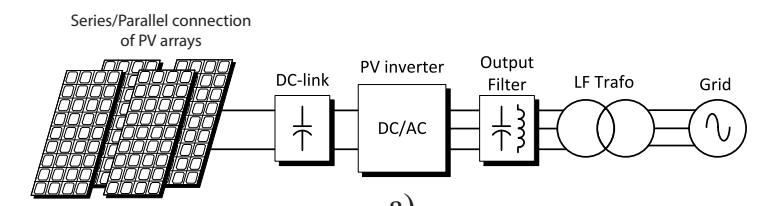

a)

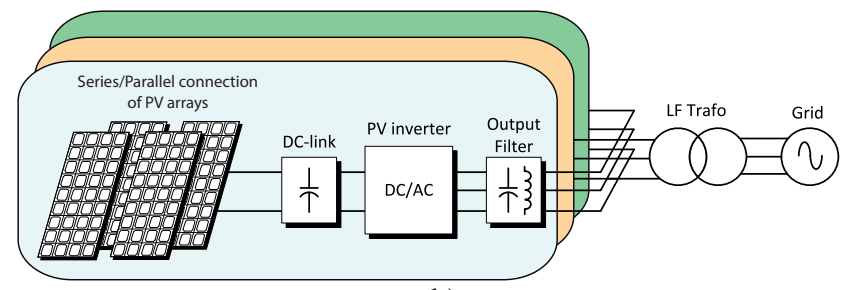

b)

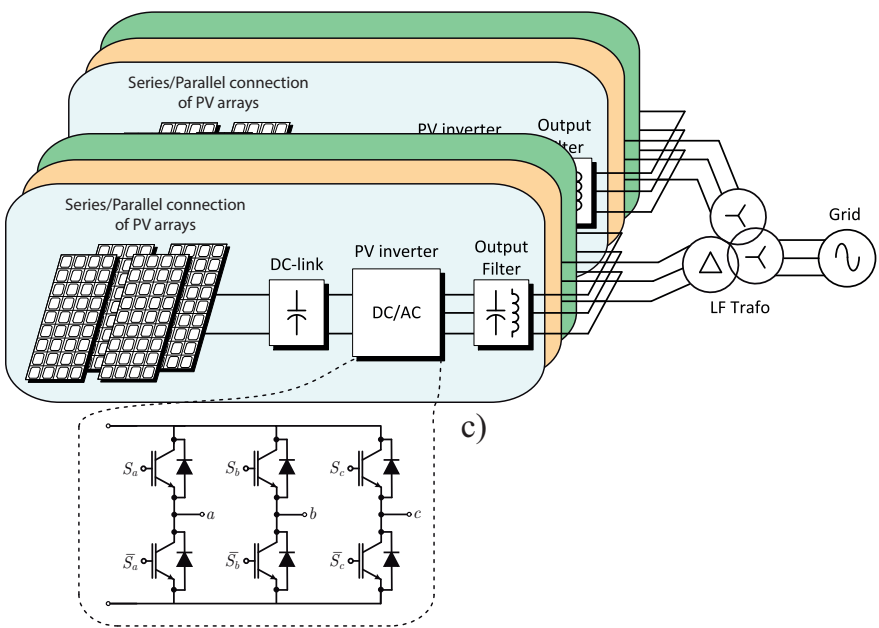

Fig. 15: General schemes of high-power PV system based on central inverters a) single-channel central inverter b) multichannel central inverter c) dual central inverter

PV arrays generate a dc voltage/current that is usually transferred by one step-up dc/dc converter to boost low PV voltage as well as track maximum power point. A dc/ac inverter connects the system to the grid or end-user (stand-alone systems) fulfilling existing grid codes (required national and international standards and regulations).

\section{GRID-CONNECTEd PV SySTEMS}

In general, the structure of a PV system can be derived from the nominal power of the system looking at highest efficiency with lowest costs [43]. Following this rule, actual PV systems can be divided into three different groups: high- power PV plants, residential and industrial PV installations, and low-power PV systems.

\section{A. PV power plants}

High-power PV plants are now being installed extensively worldwide representing a $61 \%$ of the PV market during 2015. In the last decade, the maximum power of a single PV plant has increased from $50 \mathrm{MW}$ up to more than $500 \mathrm{MW}$ in 2015 (Table II).

For high-power PV plants, the mainstream solution is to use a central three-phase inverter to connect the PV panels to the grid using a low frequency transformer. The solar panels are connected in series and in parallel in order to reach convenient values of dc voltage and nominal power respectively. The maximum dc voltage is forced by the maximum isolation allowed by the solar panel taking into account current technology and regulation (recently upgraded up to $1500 \mathrm{~V}$ ). The maximum nominal power is limited by the maximum dc voltage and the maximum current supported by the power switches. With the current PV and power switches technology and grid codes, the maximum power of a PV central inverter is around 1 MW using a conventional two-level 1700 V IGBT-based threephase inverter with a low frequency transformer (see Fig. 15a). However, some newer central inverters are based on multilevel topologies such as the TMEIC Solar Ware Samurai which is based on a T-Type three-level three phase topology in order to achieve high quality output waveforms with reduced power losses.

If the PV plant provides more power, the plant is divided to several areas, each one is managed by a central inverter independently. This solution is the most convenient from the economical point of view but the system efficiency is poor because only one MPPT controller is used for a big area of solar panels leading to a power efficiency reduction with potential partial shading and mismatch phenomena. In order to minimize this problem, a global MPPT algorithm can be specifically developed to look for the maximum power generation in the presence of other local maxima produced by partial shading phenomenon.

In order to reduce the cost of the overall installation, it is usual to arrange several central inverters in the same cabinet connecting their outputs to the same LV side of the lowfrequency transformer as represented in Fig. 15b. If a single dc voltage from the PV arrays of a large area is used as single input to the group of PV central inverters (arranged in the same cabinet), all inverters in the cabinet are not always working 

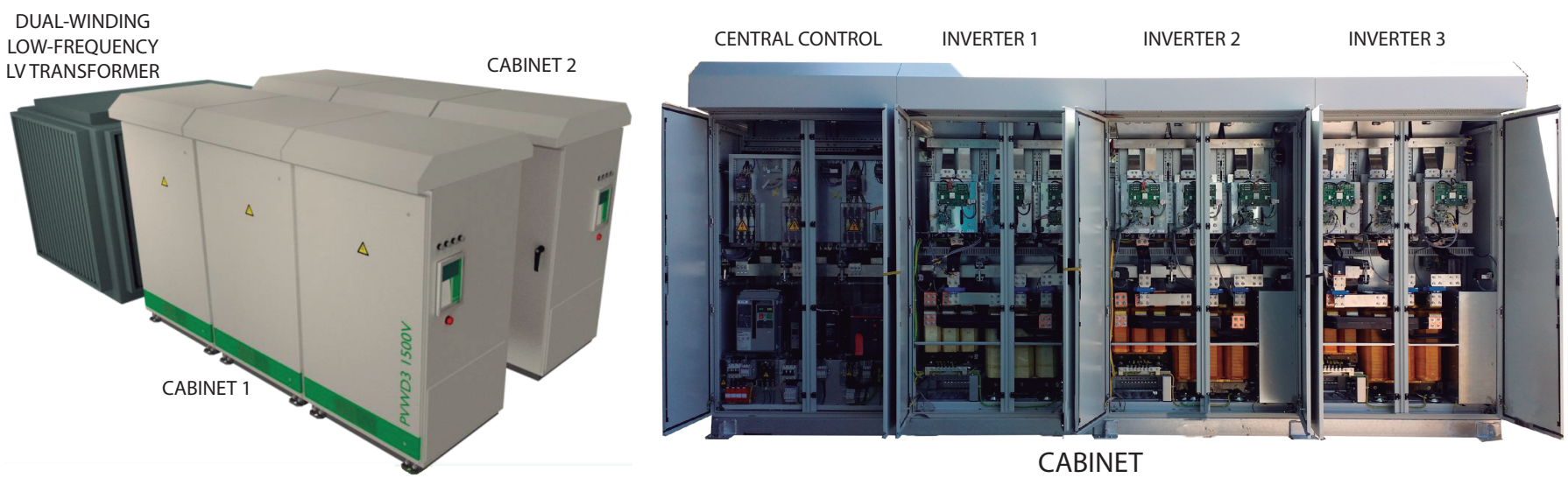

Fig. 16: 3.3 MW Multi-channel $1500 \mathrm{~V}$ central inverter PV3000WD3HV550 by GPTech based on two cabinets connected to the dual-input LV low-frequency transformer. Each cabinet is formed by three independent central inverters which can have independent dc inputs

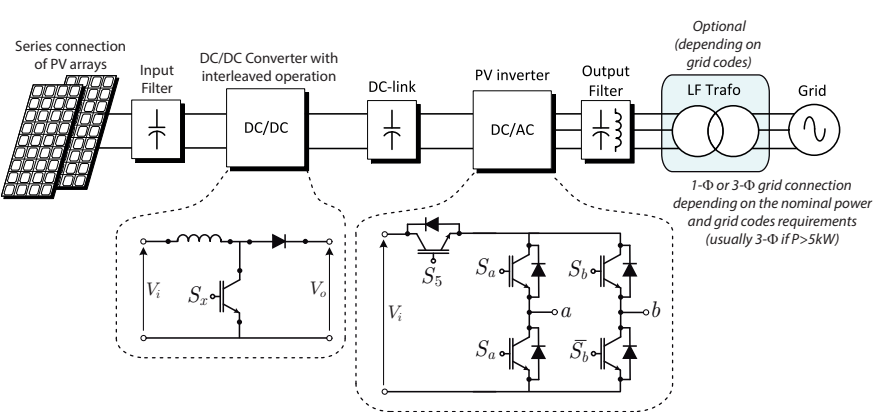

Fig. 17: General scheme of a two-stage medium-power PV system based on a string structure formed by a boost $\mathrm{dc} / \mathrm{dc}$ converter and an $\mathrm{H} 5$ inverter

simultaneously. Usually the inverters one after one starting to operate whilst the PV power is increasing. So, if the power from the PV arrays is low (less than the nominal power of a single inverter), only one inverter will be operating. This minimizes the power losses of the power converter structure. Other possible configuration is to use different $\mathrm{dc}$ inputs for each central inverter inside the cabinet. If this option is chosen, each PV central inverter inside the cabinet applies an independent MPPT controller leading to higher energy yield.

In order to achieve even higher nominal power, the trend is to connect several groups of central inverters to a sole multiwinding low frequency transformer even avoiding the use of a cabinet to reduce the price as much as possible (see Fig. 15c). For instance, this is the case of the PV3000WD3HV550 modular inverter by GPTech depicted in Fig. 16 [44].

\section{B. Residential and Industrial PV applications}

When the power of the PV system is lower than $50 \mathrm{~kW}$ approximately, the cost of the power converter is still the key but other issues such as efficiency, energy yield and distributed operation gain importance. These applications represented a $37 \%$ of the PV market in 2015. In this case, a typical structure of the PV system is the string configuration where no PV strings are connected in parallel. The converter is usually a

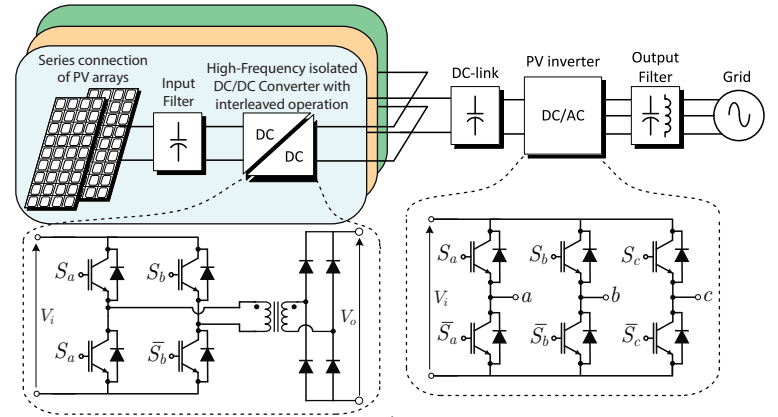

a)

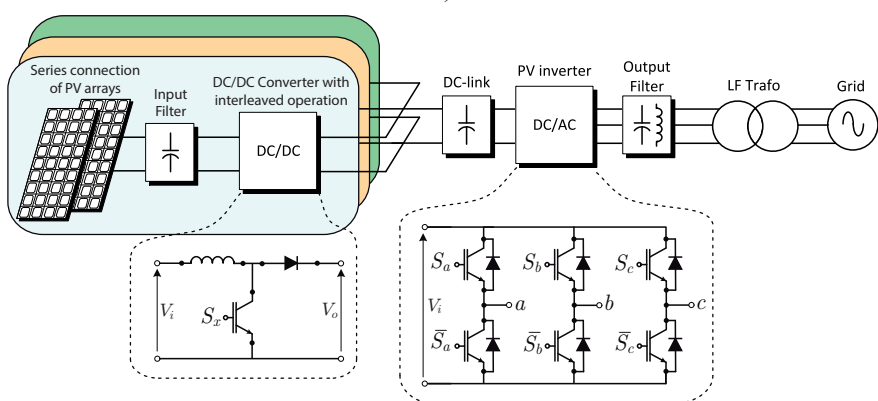

b)

Fig. 18: General schemes of a medium-power PV system based on a multi-string structure a) with high-frequency isolated dc/dc stage b) with non-isolated dc/dc stage with low frequency grid-connected transformer

two-stage structure formed by one step-up converter connected to each PV string and one grid-tied inverter. In the string configuration, the MPPT controller is related to a reduced PV area extracting power with higher efficiency compared with the central inverter structure. This is achieved at the expense of the increase of cost of the overall PV installation. This fact conventionally limits the string configuration to small scale PV systems (typically residential applications with power less than $25 \mathrm{~kW}$ ). Typical structure of a string PV converter is represented in Fig. 17 where for instance the $\mathrm{H} 5$ converter is a suitable solution. H5 (by SMA), H6 (by Ingeteam), or HERIC inverters are based on the H-bridge structure but usually 
adding extra switches in order to avoid undesirable leakage currents in the transformerless system. The H5 converter could be replaced with an h-bridge if galvanic isolation is required by the national grid code or with a conventional three-phase inverter if the nominal power is above the maximum singlephase grid connection limits imposed by the grid codes.

When the power is higher than $25 \mathrm{~kW}$, the mainstream solution is to use of multi-string solution usually built adhoc taking into account the actual operational conditions of the PV system. The multi-string configuration merges the advantages of the central inverter and the string configurations. A typical structure of a PV multi-string solution is represented in Fig. 18. Multi-string structure presents multiple PV strings and a dedicated dc/dc converter connected to each one. A single central inverter (typically three-phase) connects all $\mathrm{dc} / \mathrm{dc}$ converters to the grid. Using this configuration, each $\mathrm{dc} / \mathrm{dc}$ converter can obtain maximum power from the PV string with dedicated MPPT controllers with reduced overall system cost. The reason is that usually the cost of $\mathrm{dc} / \mathrm{dc}$ converters is lower than the cost of three-phase grid-tied inverters. In addition, the isolation of the power system can be achieved with a grid-tied low frequency transformer or with high-frequency transformers in the dc/dc stage which helps reducing the cost, weight and volume of the power system. This modular solution is popular for low- and medium-power applications (usually from 10 to $50 \mathrm{~kW}$ ) such as industrial, residential or roof-top PV systems.

Recently, the multi-string configuration has been also applied to PV systems in the range of hundreds of kilowatts [45]. In the multi-string PV system design there is a tradeoff between maximum power tracking, isolation issues and economical cost of the PV installation. The reduction of the cost of the power devices has led to make profitable this solution compared with the conventional one that is based on a central inverter but only for small PV plants. Besides, the high cost of the bulky low frequency transformer can be reduced using high-frequency transformers in the $\mathrm{dc} / \mathrm{dc}$ converter. In this case, a PV plant with multi-string converters becomes a very decentralized power system leading to advantages and disadvantages. Examples of advantages are higher yield due to multiple MPP trackers, high plant availability due to high modularity (leading to a natural faulttolerant capability), maximum flexibility in the plant design, easy transportation and fast installation. As disadvantages can be cited the initial high-cost investment for the power system, more complex communication and monitoring issues and higher power losses.

In both cases (multi-string or string configurations), if required a step-up converter, for transformerless systems the boost converter is the easiest solution (interleaved if a multistring PV system is considered) for the $\mathrm{dc} / \mathrm{dc}$ stage. For the inverter stage, several solutions have found industrial impact depending on the grid code of each country. Usually, grid codes do not allow single-phase connection to the grid if the nominal power of the PV system is above several kilowatts (5 $\mathrm{kW}$ in the Spanish regulation for instance). So, for PV systems with nominal power above this limitation, the mainstream solution for the inverter is the conventional two-level $1200 \mathrm{~V}$
IGBT-based three-phase converter. However, other solutions based on multilevel converters (neutral-point clamped or ttype) could be also found (PVS300 by ABB, not yet in the market). The advantages of using a multilevel converter topology are the higher quality of the output waveforms leading to a smaller output filter and therefore to a compact size. For PV systems with nominal power below the threephase connection grid code requirement, PV inverters are based on the extended versions of the H-bridge structure such as the H5, H6 or HERIC inverters [46]-[49].

\section{Low-power PV systems}

Roof-top PV applications are usually in the hundreds of watts (or even in the $\mathrm{kW}$ ) range and the PV converter design has to be in this case mainly focused to achieve very high efficiency with galvanic isolation and connection to a singlephase grid. Usually, the power converter is directly connected to a single PV module or a small PV array achieving $100 \mathrm{~V}$ maximum (usually the converters are installed close to the PV module working in potential harsh weather conditions). As this $\mathrm{PV}$ nominal voltage is low, it is required a two-stage power system formed by a step-up dc/dc converter and a single-phase inverter. Both converters can have different topologies and several solutions can be found in the market [50], [51]. For the dc/dc converter, high-frequency interleaved (or not) flyback or full-bridge resonant converters can be found as industrial products. For the inverter, the mainstream solution is to use a conventional $600 \mathrm{~V}$ MOSFET-based H-bridge but other power converter topologies can be also found. In Fig. 19, the typical configurations of a module-based PV system are shown. These converters can be found achieving nominal power around 250 $\mathrm{W}$ with efficiency higher than $99 \%$. As the converter is very small-size, it is usually located just back of the PV array or the PV module reducing the cabling and making easier the installation becoming a "plug\&play" system. This solution is the most efficient in terms of perfect tracking the maximum existing power from the PV module at the expense of high cost because of the high number of used power converters. Although the impact of low-power PV systems in the PV market is very limited (2\% of the PV market in 2015), the growth of module-based PV systems (microinverters) is large in the last years with high future impact.

\section{Control of Grid-Connected PV Systems}

The control structure of a grid-connected PV system depends on the converter topology used to integrate the PV arrays/modules to the grid [52], [53]. The PV converter structure, as mentioned in Fig. 14, can be single-stage based if a central inverter is used (typical for large PV power plants) or two-stage based if a first dc/dc stage is required (typical for industrial or domestic PV systems). A summary of the control scheme for a single-stage or two-stage PV converter structures is presented in Fig. 20.

In both cases (single- or two-stage), the grid-tied inverter control scheme is in most cases based on the well-known voltage-oriented control (VOC) technique normally using the 


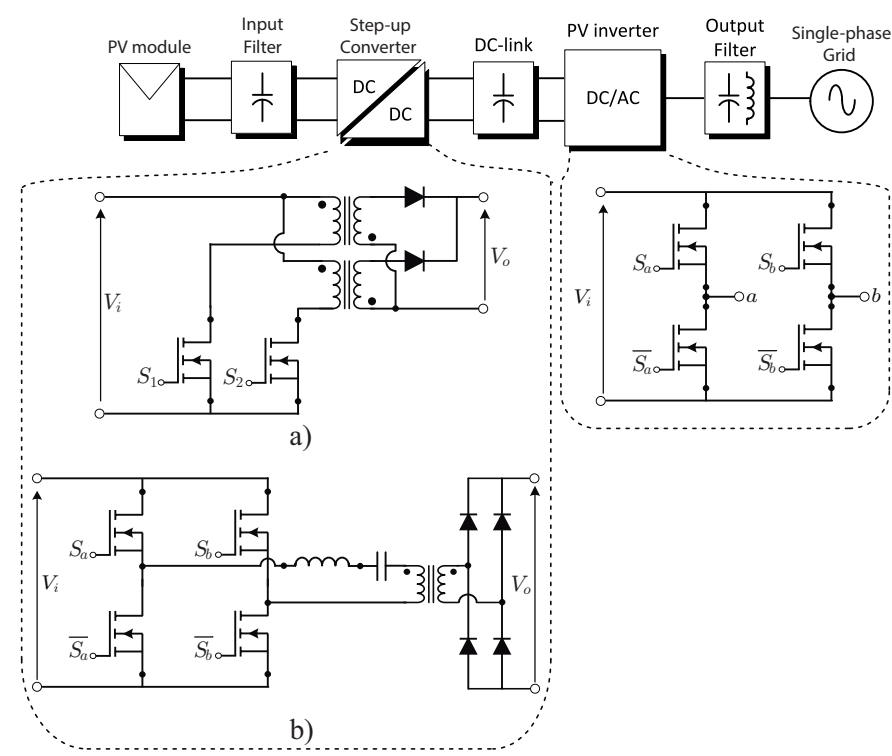

Fig. 19: General schemes of a low-power PV system based high-frequency isolated dc/dc converter and a single-phase inverter a) interleaved dc/dc high-frequency flyback converter b) resonant $\mathrm{H}$-bridge and diode bridge rectifier

synchronous $d-q$ frame (note that this is not the case in singlephase inverters) [13]. The MPPT method is executed by the inverter in the single-stage case. In the two-stage case, the MPPT is achieved by the dc-dc converter whilst the inverter accurately controls the dc-link voltage which is fixed value.

\section{STAND-ALONE PV Systems}

Stand-alone (off-grid) PV power systems lose their share in total cumulative PV capacity of global market due to dynamic development of grid-connected systems. Market share of stand-alone PV systems over the last 15 years has been reduced from $15 \%$ in 2000 to below $0.5 \%$ in 2015 [6]. However, this part of PV application has important social aspects because still there are 1.2 billion of people all over the world living without access to the electric grid and PV is most important power source for them [54]. For these people, particularly stand-alone PV installations have become a viable solution for creating hybrid systems with energy storage and gas/diesel generators as part of bigger islanded microgrids [55], [56]. This issue is becoming more attractive for research and deployment toward transforming to smart grid and solving the problems of rural areas.

Generally, stand-alone PV applications can be divided into:

- Pico PV systems $(\mathrm{P} \leq 10 \mathrm{Wp})$

- Domestic PV systems $(10 \mathrm{Wp}<\mathrm{P} \leq 10 \mathrm{kWp})$

- Commercial/Institutional PV systems (P>10kWp)

Pico PV systems are the only fast developing part of stand-alone applications taking into account the number of produced devices, which gave impressive multiple market growth during the past five years [54]. The other off-grid domestic and commercial PV installations are not similarly impressive. Their share was $70 \mathrm{MW}$ in 2015 while the cumulative capacity was $1 \mathrm{GW}$. This share is very low in comparison
TABLE III: 2015 Cumulative Capacity of Stand-Alone Solar PV Systems Worldwide [6]

\begin{tabular}{ccc}
\hline \hline Ranking & Power & Country \\
\hline 1 & $350 \mathrm{MW}$ & China \\
2 & $173 \mathrm{MW}$ & Australia \\
3 & $127 \mathrm{MW}$ & Japan \\
4 & $124 \mathrm{MW}$ & Spain \\
5 & $61 \mathrm{MW}$ & Canada \\
6 & $50 \mathrm{MW}$ & Germany \\
- & $135 \mathrm{MW}$ & All other countries \\
- & $1020 \mathrm{MW}$ & TOTAL \\
\hline \hline
\end{tabular}

to $195 \mathrm{GW}$ of total cumulative capacity of grid-connected installations. Leading countries in stand-alone systems are presented in Table III.

Power electronics converters used in stand-alone domestic and commercial PV systems are available in the portfolio of most producers and can be used in dc (only domestic) or ac (domestic and commercial) systems what is shown in Fig. 21 [57]-[60]. AC system shown in Fig. 21a is more popular because it is easily scalable, has a similar structure to public grid, its installation is simple, and extendable (gives the possibility to add other elements of smart grid like wind turbines or gas/diesel generators). It is worth mentioning that the dominant majority of installations include energy storage as a mandatory part of stand-alone system. Not least because it stores energy when there is low demand and provides more energy at peak time, but also it brings better voltage and frequency stabilization of the ac system.

One of most important parts of stand-alone PV systems is the control method of the dc/ac converter (shown in Fig. 21b). Usually, droop control is applied similarly to other well-known methods for islanded grids [61]. It assumes that converter output is inductive and the active $(P)$ and reactive power $(Q)$ to be calculated as [62]:

$$
\begin{aligned}
& P=\frac{E V}{X} \sin \varphi \\
& Q=\frac{E V \cos \varphi-V^{2}}{X},
\end{aligned}
$$

where $E$ is the converter voltage amplitude, $V$ is the filtered output voltage amplitude, $X$ is the coupling impedance and $\varphi$ is the angle between $E$ and $V$.

From equation (1), it is possible to assume that the active power depends mainly on the angle $\varphi$, which changes indirectly by the converter voltage pulsation error $\Delta \omega$. On the other hand, the reactive power depends on the converter voltage amplitude $E$ as seen from Fig. 22.

\section{ENERgy Storage Systems For PV APPliCATIONS}

Since solar energy is not always available, it should be partially stored in an efficient manner. Energy Storage Systems (ESS) can be classified as small local (up to $50 \mathrm{kWh}$ ) and distributed (with capacity above $50 \mathrm{kWh}$ ). Usage of ESS supporting power system in year 2012 (besides pumped hydro) 


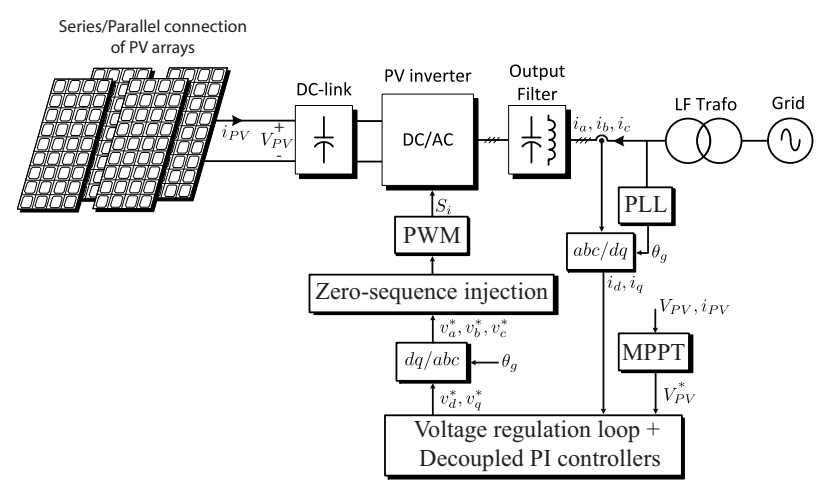

a)

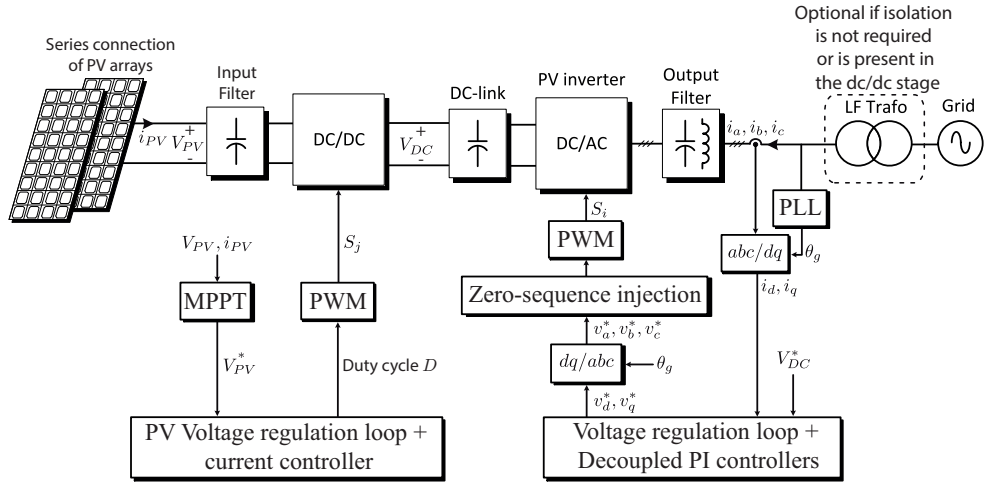

b)

Fig. 20: Control scheme of a) typical single-stage PV system for a large PV power plant b) typical two-stage PV system for industrial or domestic applications

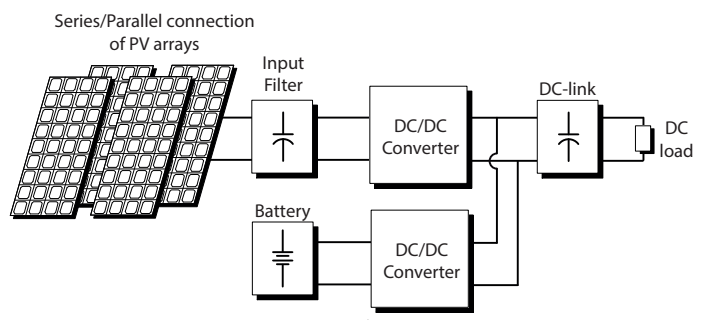

a)

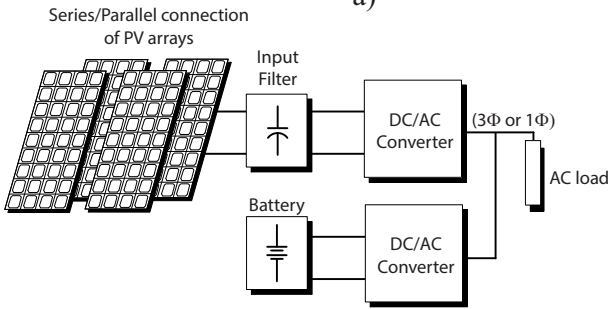

b)

Fig. 21: Configuration examples of domestic and commercial stand-alone PV systems a) simple dc based b) single or threephase ac based

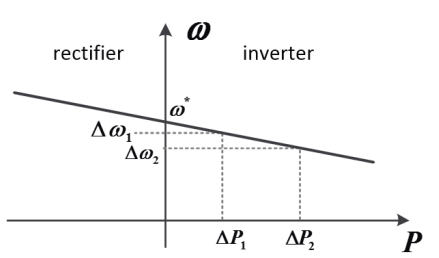

a)

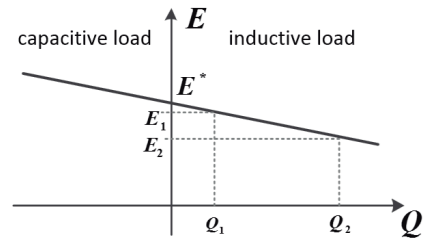

b)
Fig. 22: Droop characteristics

was based respectively on sodium-sulphur, lithium-ion, advanced lead-acid, redox-flow, and nickel-cadmium batteries. In recent years the situation changed with significantly increased installations based on lithium-ion batteries comparing to others [63], but existing capacity is still low.

Future investment and installation in energy storage is promising. The forecast shown in [63] expects a multiple annual power market capacity increase in the next years. One of significant reasons for that is the dynamic market development of electric vehicles (EV) and the utilization necessity for chemical batteries removed from EV, which can be still used (as secondary life) in ESS applied for RES or power systems. According to the scenario described in [64], cumulative installed capacity of secondary live batteries will reach $230 \mathrm{GWh}$ and $1000 \mathrm{GWh}$ in 2025 and 2030 respectively. This situation is observed by power electronics companies which currently provide plenty of converters dedicated to the ESS, what is shown in Table IV [65]-[68].

ESS installed directly to support high power PV power plants are still not common but the situation is changing due to the continuous cost reduction of battery stacks and new hard restrictions imposed by the grid codes. Examples presenting first installations are collected in Table V [69].

\section{Operational Issues of PV Systems}

The extensive installation of PV systems has come hand by hand with concerns about grid stability, grid quality and recovery, and safety of the grid maintenance staff. Requisites imposed by the grid codes of the local utility grid are known as minimum technical requirements, and renewable energy systems must comply with them to be authorized for the connection to the electric power grid. Depending on each country regulation, some standards are mandatory while others are just best practices recommendations. The standards can be classified depending on the organizations involved in its development (IEC: International Electro-technical Commission, UL: Underwriter Laboratories Inc., IEEE: Institute of Electrical and Electronics Engineers and CEN: European Committee for Standardization). A summary of standards to be fulfilled by PV converters are summarized in Table VI.

Some of the specific regulation of PV systems have been created using modified versions of regulations applied to wind power systems but other grid codes have been especially developed for PV systems. Main grid code to be fulfilled for PV systems is IEEE 1547 which is the standard for interconnecting distributed resources with electric power systems. However, it has to be noticed that nowadays regulations for PV systems vary from country to country and a worldwide standardization is still under development. 
TABLE IV: Examples of Commercial High-Power Energy Storage Systems

\begin{tabular}{cccccc}
\hline \hline Parameter & Belectric EBU 1200 & Belectric EBU Lion & ABB ESM & Siemens Siestorage & SMA sunny central storage \\
\hline Capacity & $1202 \mathrm{kWh}$ & $4016 \mathrm{kWh}$ & $6000 \mathrm{kWh}$ & $500 \mathrm{kWh}$ & up to 1.6 MW \\
Battery Technology & Lead acid & Lithium-ion & Lithium-ion & Lithium-ion & Lead acid / Lithium-ion \\
Life Cycles & up to 2000 & up to 8000 & up to 2000 & - & - \\
Max. dc voltage (V) & 1500 & 1500 & 1200 & - & 900 \\
Special functions & Black start & Black start & Black start & Black start & Black start \\
& Island operation & Island operation & Island operation & & Island operation \\
\hline \hline
\end{tabular}

TABLE V: Largest Energy Storage Installations Directly Supporting Solar PV Plants

\begin{tabular}{|c|c|c|c|c|c|}
\hline Ranking & Power/Capacity & Type of Energy Storage & Location & Solar park & On grid \\
\hline 1 & $15 \mathrm{MW} / 60 \mathrm{MWh}$ & Redox flow batteries & Hokkaido (Japan) & SoftBank Tomatoh Abira Solar Park (111MWp) & 2015 \\
\hline 2 & $\begin{array}{l}14 \mathrm{MW} / 53 \mathrm{MWh} \\
2 \mathrm{MW} / 8 \mathrm{MWh}\end{array}$ & $\begin{array}{l}\text { Lithium-ion batteries } \\
\text { Redox flow batteries }\end{array}$ & Hebei (China) & $\begin{array}{l}140 \mathrm{MW} \text { of renewable energy generation } \\
\text { (100 MW wind and 40MWp solar) }\end{array}$ & $\begin{array}{l}2011 \\
2016\end{array}$ \\
\hline 3 & $15 \mathrm{MW} / 60 \mathrm{MWh}$ & Sodium-sulfur batteries & California (USA) & Vaca Dixon Solar Plant of Vacaville (2MWp) & 2012 \\
\hline 4 & $0.5 \mathrm{MW} / 2 \mathrm{MWh}$ & Lead-acid batteries & New Mexico (USA) & Albuquerque PV park (0.5 MWp) & 2011 \\
\hline
\end{tabular}

TABLE VI: Summary of International Standards and Recommendations for PV Systems

\begin{tabular}{cl}
\hline \hline Standard & \multicolumn{1}{c}{ Focus } \\
\hline$E N 50524$ & Data sheet and name plate for photovoltaic inverters in grid parallel operation \\
$E N 50530$ & Overall efficiency of photovoltaic inverters including the procedure to measure the accuracy of the MPPT \\
$U L 1741$ & Inverters, converters, controllers and interconnection system equipment for use in stand-alone or grid-connected power systems \\
& Interconnecting distributed resources with electric power systems including voltage and frequency regulation, power quality, \\
$I E E E 1547$ & ride-through capability and anti-islanding operation \\
$I E C 61683$ & Power conditioners - Procedure for measuring efficiency \\
$I E C 62109-1$ & Safety of Power Converters for Use in Photovoltaic Power Systems - Part 1: General Requirements \\
$I E C 62109-2$ & Safety of Power Converters for Use in Photovoltaic Power Systems - Part 2: Particular Requirements for Inverters \\
\hline \hline
\end{tabular}

Grid codes regulate a lot of different aspects related to the PV power plants operation: total harmonic distortion thresholds; grounding and isolation unit faults; behavior against external conditions (dust, humidity, etc.); behavior against electric power grid faults; arc-fault detection and protection; and others. Specifically, the behavior against electric power grid faults has had a significant relevance in last years. The growth of the penetration factor of renewable energy systems in the electric power grid makes it critical to support the grid by several ancillary services preventing the total blackout of the electrical service.

Important ancillary services to the grid are the voltage and frequency excursions (deviations of the measured grid frequency or voltage in respect with its nominal value). Frequency regulation service is also a requirement defining the droop curve to be applied over the active power reference to help the system recovery to the nominal grid frequency. On the other hand, voltage regulation methods are applied when a voltage excursion is detected. In this case, the regulation is carried out by the PV system with the injection of reactive power making a contribution to the stabilization of the grid voltage at the interconnection point.

In addition, associated to the potential grid faults, frequency and voltage ride through protection methods are of concern. Ride through regulations impose that if the measured frequency or voltage reaches an error threshold continuously during a predefined time, the PV system will produce a controlled disconnection from the electric power grid. In this way, the PV power plant must keep operating to avoid a domino effect with all renewable energy systems becoming disconnected during the grid fault destabilizing the grid. And on the other hand, the PV system still connected to the grid supporting the grid by a reactive current during the grid fault.

One of the most important requirements for PV systems is the anti-islanding protection. The islanding phenomenon appears under certain conditions when a grid blackout happens and the PV system keeps operating feeding local loads without noticing the shutdown of the main grid. In this case, the PV system has to be disconnected from the grid in order to prevent hazards for the grid utility staff. In addition, it is a requirement to prevent overcurrents in the PV customer system when the grid recovers. So, anti-islanding grid codes impose that the PV control unit has to provide a disconnection before a pre-defined time after the occurrence of the fault. Detection methods of islanding condition can be divided into three main categories, which are passive inverter-resident methods, active inverterresident methods, and methods not part of the inverter structure such as the communications between the utility and the PV inverter. Active inverter-resident solutions based on methods to attempt to cause an abnormal condition in the grid voltage have gain importance in the last years reducing the power losses and the required communication between the PV system and the 
utility grid [70].

Other recent regulation for PV systems is related to a limitation of active power delivered to the grid. This requirement, also known as power curtailment, is imposed by the grid when an excess of power is present leading to a potential blackout of the system. Grid codes impose that PV systems must be equipped with a means to curtail power by remote control or to reduce drastically the active power feed-in. The PV plant operator is normally compensated for this loss but energy storage systems are now being studied to minimize the energy lost. However, nowadays there are still financial and technical barriers to be overcome as the costs for storage systems are high.

\section{Future Perspective of Solar Energy}

Research trends are mainly focused on improving the reliability, efficiency and power quality, reducing the cost, integrating with the grid at various scales and contributing in building microgrid and smart grid paradigms.

Environmental concerns have pushed up renewable energy sources revolution in the last decades, mainly wind and solar. Concentrated solar and solar photovoltaic technology are now a mature solution to obtain energy from the sun irradiation which is a free and almost endless energy source. Both concentrated or photovoltaic systems have been developed deeply in the last 25 years becoming nowadays a supporting energy player in the energy sector. The future trend of solar energy is promising with the objective of becoming one of the first energy producers of the world hand by hand with other renewable energy sources.

This future development depends on several factors. First of all, the effort of researchers will be focused on increasing the efficiency of the solar modules and reducing their cost. The use of new materials to create multi-junction solar cells will lead the future in this field.

About the solar photovoltaic power converters, the focus always will be located on maximizing the converter efficiency with minimum costs. Reliability, fault tolerant operation, easy maintenance and reduced transportation and installation costs are also factors to develop new power converter topologies for PV systems, from low to high-power. These topologies will be following the solar cells development (for instance recently PV systems isolation was upgraded to $1500 \mathrm{~V}$ leading to the appearance of a new version of commercial PV inverters). Recently, some multilevel converter topologies are already in the market and represent a promising advance in the development for PV system looking for high quality output waveforms, reduced size and cost output filters and higher efficiency. A vast use of multilevel converters for utility-scale PV systems will probably happen, if the voltage isolation regulation of the PV panels is to be revised in the future achieving central multilevel PV inverters with direct medium-voltage connection avoiding the use of low-voltage transformers and associated switchgear costs. Another trend in the new generation of PV converters will be the use of new wide band-gap power semiconductors such as $\mathrm{SiC}$ or GaN devices (as long as they become competitive in price) to improve the power density and power efficiency.
In addition, the stochastic behavior of the sun irradiation, the grid stability requirements and the maximization of economical profits will possibly force to use energy storage installations supporting PV installations to save extra energy if a power curtailment is required or adding active or reactive power if the grid demands. The development of batteries technology by improving their life-time and reducing the costs will walk hand by hand with this hybrid solution.

Therefore, R\&D sector is strongly focused to elaborate new high energy density batteries with reduced price below 150 Euro/kWh. New promising technologies of batteries which are currently under research and development are: future Li-ion (300Wh/kg), Zn-air $(400 \mathrm{Wh} / \mathrm{kg}), \mathrm{Li}-\mathrm{S}(600 \mathrm{Wh} / \mathrm{kg})$ and Li-air $(800 \mathrm{Wh} / \mathrm{kg})[64]$.

Another aspect, which can significantly improve future perspective of solar energy is broad development of dc smart grids (SG) as well as research of smart transformers (ST) [71]. This trend makes it possible for easy integration and fully utilization of PV energy and storage elements which eliminates additional power converters and improves overall efficiency and energy security.

Finally, but also important, the vast development of solar energy systems also depends strongly on the governments and the required strong support to develop and implement renewable energy sources. This was in the past based on feed-in tariff policies to accelerate the development of renewable energy source technology, which now can be considered mature. Now, the politician efforts have to be focused on creating a friendly scenario to create a distributed electrical grid system not very dependant on gas/coal-based or nuclear plants.

\section{Conclusions}

Solar energy systems (photovoltaic and concentrated) have become a mature and promising technology worldwide. The paper has shown that the solar energy has been shaped to be an essential element of the present and future energy scenarios. The continuous development of materials have led to new families of solar systems that are more efficient, compact, and cheap. This have led to profitable installations and investments to take advantage of the endless sun power. This paper summarizes the current status of solar energy technology and provides a comprehensive overview of this vital sector by addressing the facts, challenges, and solutions from the past, present and future projection.

\section{REFERENCES}

[1] H. Abu-Rub, M. Malinowski, and K. Al-Haddad, Power Electronics for Renewable Energy Systems, Transportation and Industrial Applications. John Wiley \& Sons, Ltd, 2014, pp. 1-729.

[2] "World energy outlook 2015," in International Energy Agency (IEA), 2015.

[3] O. Ellabban, H. Abu-Rub, and F. Blaabjerg, "Renewable energy resources: Current status, future prospects and their enabling technology," Renewable and Sustainable Energy Reviews, vol. 39, pp. 748-764, November 2014.

[4] "Medium-term renewable energy market report 2015-market analysis and forecasts to 2020," in International Energy Agency (IEA), 2015.

[5] M. Malinowski, A. Milczarek, R. Kot, Z. Goryca, and J. T. Szuster, "Optimized energy-conversion systems for small wind turbines: Renewable energy sources in modern distributed power generation systems," IEEE Power Electronics Magazine, vol. 2, no. 3, pp. 16-30, Sept 2015. 
[6] "Trends 2016 in photovoltaic applications," in Photovoltaic Power Systems Programme, International Energy Agency (IEA), online available at http://iea-pvps.org, 21st edition 2016.

[7] "Renewables 2016 global status report," in Renewable Energy Policy Network for the 21st Century (REN21), 2016.

[8] "Technology roadmap solar photovoltaic energy," in International Energy Agency (IEA), 2014.

[9] "Statistische zahlen der deutschen solarstrombranche (photovoltaik)," in BSW-Solar, 2011

[10] "Photovoltaic system pricing trends," in Solar Energy Industries Association (SEIA), 2011.

[11] "Eia us energy inf. adm.: Updated capital cost estimates for utility scale electricity generating plants," 2016.

[12] "Renewable power generation costs," in International Renewable Energy Agency, online available at www.irena.org, 2014.

[13] E. Romero-Cadaval, B. Francois, M. Malinowski, and Q. C. Zhong, "Grid-connected photovoltaic plants: An alternative energy source, replacing conventional sources," IEEE Industrial Electronics Magazine, vol. 9, no. 1, pp. 18-32, March 2015.

[14] C. Jin and W. Jiang, "Design of a digital controlled solar water pump drive system for a nano-filtration system," in 2011 IEEE Ninth International Conference on Power Electronics and Drive Systems, Dec 2011, pp. 982-986.

[15] L. J. Olatomiwa, S. Mekhilef, and A. S. N. Huda, "Optimal sizing of hybrid energy system for a remote telecom tower: A case study in nigeria," in 2014 IEEE Conference on Energy Conversion (CENCON), Oct 2014, pp. 243-247.

[16] D. Chandran, M. Joshi, and V. Agarwal, "Solar pv based retrofit solution for cell phone towers powered by diesel generators," in 2016 IEEE International Telecommunications Energy Conference (INTELEC), Oct 2016, pp. 1-8.

[17] P. Zhao, S. Suryanarayanan, and M. G. Simoes, "An energy management system for building structures using a multi-agent decision-making control methodology," IEEE Transactions on Industry Applications, vol. 49, no. 1, pp. 322-330, Jan 2013

[18] J. Han, C. s. Choi, W. k. Park, I. Lee, and S. h. Kim, "Smart home energy management system including renewable energy based on zigbee and plc," IEEE Transactions on Consumer Electronics, vol. 60, no. 2, pp. 198-202, May 2014.

[19] W. Benomar, H. Zennouhi, A. Arid, T. E. Rhafiki, A. A. Msaad, and T. Kousksou, "Storage of solar energy in pcm building construction," in 2015 3rd International Renewable and Sustainable Energy Conference (IRSEC), Dec 2015, pp. 1-6.

[20] K. Strunz, E. Abbasi, and D. N. Huu, "Dc microgrid for wind and solar power integration," IEEE Journal of Emerging and Selected Topics in Power Electronics, vol. 2, no. 1, pp. 115-126, March 2014.

[21] C. Zhang and Y. J. Zhang, "Optimal solar panel placement in microgrids," in 2016 IEEE International Conference on Smart Grid Communications (SmartGridComm), Nov 2016, pp. 376-381.

[22] G. R. C. Mouli, P. Bauer, and M. Zeman, "System design for a solar powered electric vehicle charging station for workplaces," Applied Energy, vol. 168, pp. 434-443, April 2016.

[23] A. F. Morgera and V. Lughi, "Frontiers of photovoltaic technology: A review," in 2015 International Conference on Clean Electrical Power (ICCEP), June 2015, pp. 115-121.

[24] M. A. Green, K. Emery, Y. Hishikawa, W. Warta, and E. D. Dunlop, "Solar cell efficiency tables (version 48)," Progress in Photovoltaic: Research and Applications, Hoboken, NJ: John Wiley \& Sons Ltd., Nov 2016.

[25] "CSP facts \& figures," online available at http://www.cspworld.org/resources/csp-facts-figures, Jun. 2012, retrieved 22 Apr. 2013

[26] M. Labordenaa, A. Patta, M. Bazilianb, M. Howellsb, and J. Lilliestama "Impact of political and economic barriers for concentrating solar power in sub-saharan africa," Energy Policy, vol. 102, pp. 52-72, March 2017.

[27] D. M. Tagare, Photovoltaic EnergySolar Cells and Solar Power Systems. Wiley-IEEE Press, 2011, pp. 195-216. [Online]. Available: http://ieeexplore.ieee.org/xpl/articleDetails.jsp?arnumber=5713329

[28] A. Reinders, P. Verlinden, W. van Sark, and A. Freundlich, Photovoltaic Solar Energy: From Fundamentals to Applications. Wiley, 2017.

[29] S. Chakraborty, M. G. Simoes, and W. E. Kramer, Power Electronics for Renewable and Distributed Energy Systems. Springer, 2013.

[30] R. F. K. A. D. Chung, C. Davidson and R. Margolis, "S photovoltaic prices and cost breakdowns: Q1 2015 benchmarks for residential, commercial, and utility-scale systems," NREL Technical Report, 2015.

[31] "2014 snapshot of global pv markets," in International Energy Agency (IEA), 2015.
[32] "8 solar trends to follow in 2015," online at http://www.greentechmedia.com, Jan. 2015.

[33] N. Femia, G. Petrone, G. Spagnuolo, and M. Vitelli, Power Electronics and Control Techniques for Maximum Energy Harvesting in Photovoltaic Systems. CRC Press, 2012.

[34] T. Adefarati and R. C. Bansal, "Integration of renewable distributed generators into the distribution system: a review," IET Renewable Power Generation, vol. 10, no. 7, pp. 873-884, 2016.

[35] Q. Zhou, C. Xun, Q. Dan, and S. Liu, "Grid-connected pv inverter reliability considerations: A review," in 2015 16th International Conference on Electronic Packaging Technology (ICEPT), Aug 2015, pp. 266-274.

[36] M. K. Alam, F. Khan, J. Johnson, and J. Flicker, "A comprehensive review of catastrophic faults in pv arrays: Types, detection, and mitigation techniques," IEEE Journal of Photovoltaics, vol. 5, no. 3, pp. 982-997, May 2015.

[37] "Top 10 largest solar photovoltaic plants in the world," online available at http://www.imeche.org, May. 2016.

[38] T. D. Lee and A. Ebong, "Thin film solar technologies: a review," in 2015 12th International Conference on High-capacity Optical Networks and Enabling/Emerging Technologies (HONET), Dec 2015, pp. 1-10.

[39] "Photovoltaics report," in Fraunhofer Institute for Solar Energy Systems, ISE with support of PSE AG Freiburg, Nov. 2016.

[40] "Energy trend trend charts," online available at http://pv.energytrend.com.

[41] "Solar power plants: Large-scale pv," online available at http://www.ucsusa.org, Dec. 2015.

[42] S. Kouro, J. I. Leon, D. Vinnikov, and L. G. Franquelo, "Grid-connected photovoltaic systems: An overview of recent research and emerging pv converter technology," IEEE Industrial Electronics Magazine, vol. 9, no. 1, pp. 47-61, March 2015.

[43] E. Romero-Cadaval, G. Spagnuolo, L. G. Franquelo, C. A. Ramos-Paja, T. Suntio, and W. M. Xiao, "Grid-connected photovoltaic generation plants: Components and operation," IEEE Industrial Electronics Magazine, vol. 7, no. 3, pp. 6-20, Sept 2013.

[44] "Solutions for utility-scale, power management and grid integration," GreenPower Tech, online available at www.greenpower.es/en, 2015.

[45] "Advisory guide - decentralized inverter technology in large-scale pv plants," SMA Solar Technology AG, 2013.

[46] R. Teodorescu, M. Liserre, and P. Rodriguez, Grid Converters for Photovoltaic and Wind Power Systems. United States: Wiley-IEEE press, 12011.

[47] T. K. S. Freddy, N. A. Rahim, W. P. Hew, and H. S. Che, "Comparison and analysis of single-phase transformerless grid-connected pv inverters," IEEE Transactions on Power Electronics, vol. 29, no. 10, pp. 5358 5369, Oct 2014

[48] H. Jedtberg, A. Pigazo, M. Liserre, and G. Buticchi, "Analysis of the robustness of transformerless pv inverter topologies to the choice of power devices," IEEE Transactions on Power Electronics, vol. PP, no. 99, pp. 1-1, 2016.

[49] L. Zhang, K. Sun, Y. Xing, and M. Xing, "H6 transformerless full-bridge pv grid-tied inverters," IEEE Transactions on Power Electronics, vol. 29, no. 3, pp. 1229-1238, March 2014.

[50] D. Meneses, F. Blaabjerg, . García, and J. A. Cobos, "Review and comparison of step-up transformerless topologies for photovoltaic acmodule application," IEEE Transactions on Power Electronics, vol. 28, no. 6, pp. 2649-2663, June 2013.

[51] R. Kosenko, "State of the art review of pv module-level power electronics," in Doctoral School of Energy and Geotechnology II : closing conference of the project, Jan Pärnu, Estonia, 2015, pp. 146-151.

[52] G. Petrone, C. A. Ramos-Paja, and G. Spagnuolo, Control of the Power Conversion Chain. Wiley-IEEE Press, 2016, pp. 208[Online]. Available: http://ieeexplore.ieee.org/xpl/articleDetails.jsp? arnumber $=7853779$

[53] W. Xiao, Photovoltaic Power System: Modelling, Design and Control. Wiley, 2017.

[54] "Off-grid solar market trends report 2016," online available at www.ifc.org, Feb. 2016

[55] C. Protogeropoulos, S. Tselepis, and A. Neris, "Research issues on stand-alone pv/hybrid systems: state-of-art and future technology perspectives for the integration of grid topologies on local island grids," in 2006 IEEE 4th World Conference on Photovoltaic Energy Conference, vol. 2, May 2006, pp. 2277-2282.

[56] Y. Kojima, M. Koshio, S. Nakamura, H. Maejima, Y. Fujioka, and T. Goda, "A demonstration project in hachinohe: Microgrid with private distribution line," in 2007 IEEE International Conference on System of Systems Engineering, April 2007, pp. 1-6. 
[57] Information available at https://www.sma.de/en/home-systems/solarsystem-off-grid.html.

[58] Information available at http://www.tsolpv.com/en/index.php.

[59] Information available at http://www.eastups.com.

[60] Information available at http://solar.schneiderelectric.com/solution/residential-off-grid-solar/.

[61] A. Trzynadlowski, "Power electronic converters and systems: Frontiers and applications," in IET Power and Energy Series, 2015.

[62] J. M. Guerrero, N. Berbel, J. Matas, J. L. Sosa, and L. G. de Vicuna, "Droop control method with virtual output impedance for parallel operation of uninterruptible power supply systems in a microgrid," in APEC 07 - Twenty-Second Annual IEEE Applied Power Electronics Conference and Exposition, Feb 2007, pp. 1126-1132.

[63] "Battery storage for renewables: market status and technology outlook," in International Renewable Energy Agency, online available at www.irena.org, Jan. 2015.

[64] G. Reid and J. Julve, "Second life-batteries as flexible storage for renewable energies," in Bundesverband Erneuerbare Energie e.V. (BEE), Hannover Messe, April 2016.

[65] Information available at http://www.belectric.com.

[66] Information about siestorage available at http://w3.siemens.com/powerdistribution/global/en/mv/.

[67] Information available at http://www.sma.de/en/products/batteryinverters/.

[68] Information available at http://new.abb.com/medium-voltage/modularsystems/energy-storage-modules.

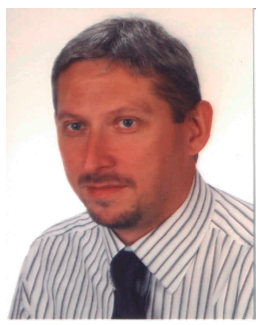

Mariusz Malinowski (S'99, M'03, SM'08, F'13) received the Ph.D. and D.Sc. degrees in electrical engineering from the Institute of Control and Industrial Electronics, Warsaw University of Technology (WUT), Warsaw, Poland, in 2001 and 2012, respectively.

He was a Visiting Scholar at Aalborg University, Aalborg, Denmark; the University of Nevada, Reno, NV, USA; the Technical University of Berlin, Berlin, Germany; and ETH Zurich, Zurich, Switzerland. $\mathrm{He}$ is currently with the Institute of Control and Industrial Electronics, WUT. His current research interests include the control and the modulation of grid-side converters, multilevel converters, smart grids, and power-generation systems based on renewable energies. He has coauthored over 130 technical papers and six books. He holds two implemented patents.

Prof. Malinowski was the recipient of the Siemens Prize in 2002 and 2007; the WUT President Scientific Prize in 2015; the Polish Minister of Science and the Higher Education Awards in 2003 and 2008; the Prime Minister of Poland Award for Habilitation in 2013; and the IEEE Industrial Electronics Society (IES) David Irwin Early Career Award in 2011 and Bimal Bose Energy Systems Award in 2015. His industry application received several awards and medals, the Innovation Exhibition in Geneva in 2006 and the Exhibition in Brussels "Eureco" in 2006.
[69] Information available at http://www.sandia.gov/ess/doe-global-energystorage-database/.

[70] S. Kouro, B. Wu, H. Abu-Rub, and F. Blaabjerg, Photovoltaic Energy Conversion Systems. John Wiley \& Sons, Ltd, 2014, ch. 7, pp. 160-198. [Online]. Available: http://dx.doi.org/10.1002/9781118755525.ch7

[71] M. Liserre, G. Buticchi, M. Andresen, G. D. Carne, L. F. Costa, and Z. X. Zou, "The smart transformer: Impact on the electric grid and technology challenges," IEEE Industrial Electronics Magazine, vol. 10, no. 2, pp. 46-58, June 2016.

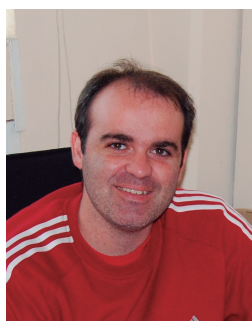

Jose I. Leon (S'04-M'07-SM'14) was born in Cádiz, Spain. He received the B.S. and M.S. and $\mathrm{PhD}$ degrees in telecommunications engineering from Universidad de Sevilla (US), Spain, in 1999, 2001 and 2006 respectively.

Currently, he is an Associate Professor with the Department of Electronic Engineering, US. His research interests include modulation and control of power converters for high-power applications and renewable energy systems.

Dr. Leon was recipient as co-author of the 2008 Best Paper Award of the IEEE Industrial Electronics Magazine, the 2012 Best Paper Award of the IEEE Transactions on Industrial Electronics, and the 2015 Best Paper Award of the IEEE Industrial Electronics Magazine. He was the recipient of the 2014 IEEE J. David Irwin Industrial Electronics Society Early Career Award and is currently serving as an Associate Editor of the IEEE Transactions on Industrial Electronics.

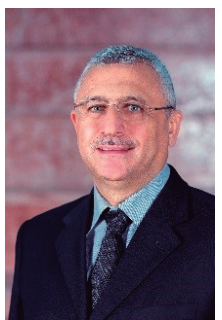

Haitham Abu-Rub (M'99-SM'07) is a full professor holding two PhDs from Gdansk University of Technology (1995) and from Gdansk University (2004). Dr. Abu Rub has long teaching and research experiences at many universities in many countries including Poland, Palestine, USA, UK, Germany and Qatar.

Since 2006, Dr. Abu-Rub has been associated with Texas A\&M University at Qatar, where he is currently the chair of Electrical and Computer Engineering program and the Managing director of the Smart Grid Center - Extension in Qatar.

His main research interests are energy conversion systems, smart grid, renewable energy systems, electric drives, and power electronic converters. Dr. Abu-Rub is the recipient of many prestigious international awards and recognitions, such as the American Fulbright Scholarship and the German Alexander von Humboldt Fellowship. He has co-authored more than 250 journal and conference papers, five books, and five book chapters. 